\title{
The Internationalisation of Higher Education
}

\section{Institutes (HEIs) in the Southern Africa Development Community (SADC): A comparative content analysis}

\author{
Mashombotwa Mukwena \\ University of University (UNILUS), Lusaka, Zambia
}

\begin{abstract}
In the thrust to achieve the goal of internationalisation, the mission statements of Higher Education Institutes (HEIs) serve as a standard to guide the translation of policy into practice. Since the first organisational guide by Drucker in 1974, mission statements have become normative in all sectors including education. Pedagogical challenges caused by the COVID-19 pandemic in education sectors the world over has led to immense discourse regarding internationalisation, a concept substantially debated even before the pandemic. This study takes stock of the current standing of 127 mission statements from HEIs in Southern Africa. Additionally, a comparative analysis between the SADC mission statements and 164 HEIs from the world's Top 200 Universities in 2020. A quantitative content analysis approach utilising Voyant Tools (C) software allowed for a large volume of text (corpus) to be analysed and meaningful aggregates produced. This approach does not utilise hypotheses or pre-set taxonomies allowing for exploratory inductive data analysis. Previous studies have been restricted to country contexts with no open access data and based on small samples. This study established that both datasets (SADC and Top 200) exhibited similar global tenets of mission statement components. However, notable differences exist with SADC mission statements attempting to align themselves with the goal of contributing to their respective nations' economic development. The global (Top 200) dataset's international orientation focused on student exchanges and collaborative research while in SADC provision of high-quality education meeting international standards is the focus. The study recommends that post pandemic realignment of mission statements in accordance to the intended internationalisation goal is required to ensure policy to practice harmonisation.
\end{abstract}

Keywords: Mission statements, Content analysis, SADC, Higher Education

\section{INTRODUCTION}

$\mathrm{H}$ igher Education Institutes (HEIs) globally have been shaken to the core due to the Covid-19 pandemic. While knowledge (embedded in curriculum) remained unscathed the pandemic disrupted the way in which knowledge is taught and the processes of HEIs (Peters et al, 2020). Majority of HEIs opted to undertake "internationalisation at home" through curriculum integration of international education. There is a need to regularly review HEIs positioning and strategies especially in the wake of the disruption caused by the pandemic (Salgado, 2020). Academics in higher education have a long way to go in responsive investigations to changing environments (Oleksiyenko, 2020). Prior to the pandemic the concept of internationalisation toggled between competition and collaboration driven. There are calls now for collaboration to be the main driver for the betterment of the global citizenry (Peters et al, 2020). Perhaps it is time to revisit this and align the strategies of HEIs with a collaborative ethos (Gimenez, 2020).

The present and future international intentions of a HEI can be measured through their mission statement (Ketterer, 2015). In the education sector mission statements have become a vital strategic component (Ganu, 2013) to both communicate the direction of the institution as well as drive its operations and performance (Ozdem, 2011). HEIs utilise mission statements as identity narratives and studies have shown that HEIs form clusters of narratives dependent on their similarities (Kosmützky and Krücken, 2015). Within a cluster each HEI is then able to differentiate themselves to gain a competitive edge. This differentiation is seen especially between HEIs that are in close geographical proximity to one another (Seeber, 2017). Critics have stressed that mission statements should be analysed with caution because what is expressed in their content may be far from the HEI's real behaviour and beliefs (Alegre, 2018). A stock of the content of Southern African HEIS mission statements is long overdue. This stock take is required in order to navigate the new normal of HEIs.

The following research questions guided the study:

1. How do the mission statements of the SADC region differ in their expression of internationalisation?

2. How do internationalisation expressions differ between the mission statements of SADC countries versus the Times Higher Education (THE) top 200 HEIs?

\section{LITERATURE REVIEW}

The majority of HEIs make reference to their international dimension in their mission statements (Kehm, 2007). Evidence of this was captured in the 5th International Association of Universities (IAU) Global Survey of 907 HEIs from 126 countries. More than 90\% surveyed made reference to internationalisation in their mission statements and strategic plans (Marinoni, 2019). The current internationalisation of higher education is market-driven due to globalisation 
creating a competitive environment (Gimenez, 2020; Dumanig, 2020). The definition of the term and its application has evolved over the decades and the quest continues (even post pandemic) for a comprehensive definition applicable to many countries in a range of contexts but allowing for comparability (Knight, 2003; Knight 2013). An example is the 186 indicators that have been identified as internationalisation measurement tools in a range of various contexts (Brandenburg et al., 2007). Several internationalisation indexes utilise parameters such as the articulated commitment by HEIs (Sambatur, 2007). The Times Higher Education (THE) World University Rankings also utilise a parameter termed "international outlook" in its ranking computation. These various measurement techniques emphasize the ever growing importance of internationalisation in higher education.

Mission statement studies have focused on individual countries with few comparability studies across borders (Cortés-Sánchez, 2018; Vasudeva, 2020). Additionally, the communication of internationalisation is complex, compounded by various interpretations and approaches (Jowi, 2013; Teichler, 2004). Several studies have called for regional and international analysis of mission statements (Mukwena, 2020; Vasudeva 2020), especially on the African continent (Mogaji et al., 2017). Lack of sufficient data for comparative analysis and decision-making was found to be one of the key hindrances of internationalisation in higher education in a 17country study (10 European and 7 other continents) carried out by the European Parliament's Committee on Culture and Education (De Wit et al, 2015). In the 2000s, the decade saw only 6 studies utilising text mining (quantitative approach) carried out in the field of education representing $1.3 \%$ of research (Jung, 2020).

This study firstly contributes to the limited text mining mission statement undertakings especially in the field of higher education. The study will secondly add to the few global south mission statement studies forming a foundation for future research. Creating empirical studies comparing the global south to the global north will aid policy makers, HEI administrators and relevant stakeholders to begin targeted responses at institutional, sectorial and national levels to advance the internationalisation agenda in their respective countries. Few content analysis studies delve into how internationalisation is represented in mission statements (Dumanig, 2020). This study will create the first open access Voyant Tools (C) dataset for mission statements in Southern Africa and begin the discussion on future comparative quantitative studies in the field of Higher Education.

\section{Conceptualisation of Internationalisation}

At its genesis in the 1980s the term internationalization was defined as a set of activities within international education exchanges (Knight 2004). This activity approach described the term in categories such as curriculum or staff and student exchanges. By the 1990s the term broadened to encompass a process approach defined as the "process of integrating an international and intercultural dimension into the teaching, research and service functions of an institution" (Knight, 2004). This widely adopted definition encompassed a wide range of activities and procedures. The definition was revised by Knight in 2003 to reflect globalisation propelled by the definition's need to cater to the globally diverse HEIs as well as applicability at institutional, national and global level. Each level has different rationales for internationalisation from economic, political, social, cultural and academic (Gyamera, 2019; Salgado, 2020). These complexities have left internationalisation a contentious concept (IAU, 2010).

A recently coined definition offers an improvement on Knight's interpretation with more emphasis on the nature and purpose of internationalization:

"Internationalization is the intentional process of integrating an international, intercultural or global dimension into the purpose, functions and delivery of post-secondary education, in order to enhance the quality of education and research for all students and staff, and to make a meaningful contribution to the society" (de Wit et al., 2015)

There has been a differentiation between cross border internationalisation versus internationalisation at home. The former is exhibited predominantly in developed countries through the hosting of foreign students (Altbach \& Knight, 2007) or mobility of students and staff (Knight, 2013). Internationalisation at home is carried out through formal and informal curriculum integration of international education undertaken within the borders of a country (De Wit, 2018).

Several interpretations and classification attempts of the term internationalization exist (Knight, 2013). Most notably Teicher (2017) and Helms et. al (2015) categorized the term into six and five interpretations respectively. Collectively the interpretations include the cross-border transfer of knowledge through mediums such as books. This interpretation takes on a competency approach. Other interpretations include: student and staff mobility across borders; cooperation in research; internationalisation at home; global convergence of education to cope with the global academic ecosystem (Altbach \& Knight, 2007) and the strive for international recognition as a world class institution. A study of three universities in Ghana found internationalisation to be interpreted as the global acceptance of a university (Gyamera, 2019). These interpretations suggest that internationalization is not a goal but a means to achieve quality education (De Wit, 2018). In the African context there is concern that the term has been aligned to globalisation so much so that regionalisation of the continent has been ignored (Majee, 2020).

\section{Higher Education in SADC}

Southern Africa's colonial history that suppressed indigenous learning resulted in HEIs being constructed with a western education framework (Masaiti, 2020; Damdew, 2012). The first generation of graduates in the 1960 s were a product of 
these newly formed HEIs. Despite this forced adoption of western education framework, the region and continent as a whole remains globally overlooked with marginal international collaborations (Alemu, 2014; Tamrat, 2018; Altbach and Knight, 2007). The 1970s and 1980s saw mass student mobility with developed countries hosting foreign students in the hope that they would return to help their respective countries' development. Initially, this type of exchange formed the first interpretations of the term internationalisation. Many graduates however did not return to their countries in what was coined the "brain drain". Higher Education further suffered when education funding focused on basic education to tackle high illiteracy levels. Recently however, regional student mobility in SADC has been enhanced through students being charged within the region at the same rate as nationals in the country of study.

Regional research partnerships have been formed such as the Organisation for Social Science Research in Eastern and Southern Africa (OSSREA) that offer opportunities for HEIs to cement their institutional capacity (Jowi, 2013). Southern African Regional Universities Association (SARUA) enables collaborative partnerships in research and HEIs capacity building. Attempts have been made to integrate policies within the region with the signing in 1997 of The SADC Protocol on Education and Training by 12 countries. This policy framework provides for regional cooperation and integration of the entire region's education sector such as the agreement for members to reserve $5 \%$ of their student enrolment for SADC applicants (Hahn, 2017). These regional initiatives all exist without replacing each country's national identity (Knight, 2013). Regarding mission statements, the SADC region has been guided by collaborative efforts such as UNESCO's report 'The African University: Into the New Millennium'. This report guides that a mission statement should differentiate the HEI's functions of teaching, research and service to society. This differentiation can be expressed differently however the same ethos should apply for all universities of all regions in Africa (Farrant, 1996).

\section{Mission Statement Studies on Internationalisation}

A contemporary study on African HEIs mission statements found that the majority wish to perform three functions namely teaching, research and service to society (Vasudeva, 2020). These findings are in line with the three functions outlined in the UNESCO's report 'The African University: Into the New Millennium'. The influence of global competition is evident in Vasudeva's study whose findings state that HEIs wish to produce graduates able to compete globally. The study however analysed only 36 HEIs on the continent and utilized human thematic analysis. Each mission statement was read to analyse if it addressed the five key questions a mission statement must address. These five questions created by Arias-Coello et al. (2018) are an improvement on the outdated eight mission statement components created by Pearce and David's (1987).
Vasudeva's study's qualitative approach limits the volume of content that can be analysed.

The stated presence of internationalisation in mission statements has been carried out in a global south study by Guinmares in 2019. The study firstly checked each of the 62 Brazilian HEI's mission statements for the term and its related words such as "international". Only 7 HEIs were found to contain the term. Additionally, the study utilised quantitative analysis (on the HEIs that did not contain the term "international") utilising "Sketch Engine" software to produce word frequencies. The highest frequency words (in descending order) were knowledge, development and society (Guimares, 2019).

\section{RESEARCH METHODOLOGY}

\section{Datasets}

The SADC region comprises of 16 member States; Angola, Botswana, Comoros, Democratic Republic of Congo, Eswatini, Lesotho, Madagascar, Malawi, Mauritius, Mozambique, Namibia, Seychelles, South Africa, Tanzania, Zambia and Zimbabwe. Each country's higher education regulator's website was searched for a list of registered HEIs. The websites of these HEIs were searched for their mission statement. Only mission statements in English were considered. The Voyant Tools (C) datasets utilised can be viewed using the following links.

SADC:

https://voyanttools.org/?corpus $=68 \mathrm{f} 373 \mathrm{c} 5 \mathrm{eb} 77 \mathrm{~b} 95 \mathrm{~b} 1 \mathrm{~b} 9 \mathrm{~b} 3 \mathrm{db} 5 \mathrm{aa} 73067 \mathrm{~d}$

WORLD: $\quad$ https://voyanttools.org $/$ ?corpus $=899 \mathrm{~b} 7 \mathrm{da} 6 \mathrm{bae} 5 \mathrm{f529 \textrm {d } 6 \mathrm { d } 0 8 2 5 \mathrm { aee } 3 6 9 4 \mathrm { cb }}$

Table 1 - Number of mission statements found in each SADC country

\begin{tabular}{|c|c|}
\hline & $\begin{array}{c}\text { Number of Mission } \\
\text { Statements }\end{array}$ \\
\hline Botswana & 7 \\
\hline Eswatini & 11 \\
\hline Lesotho & 3 \\
\hline Madagascar & 1 \\
\hline Malawi & 6 \\
\hline Mauritius & 6 \\
\hline Namibia & 3 \\
\hline South Africa & 17 \\
\hline Tanzania & 18 \\
\hline Zambia & 45 \\
\hline Zimbabwe & 10 \\
\hline Total & 127 \\
\hline
\end{tabular}

The 2020 Times Higher Education (THE) publication of the World's top Universities is generated using performance indicators that are grouped in the five areas of Teaching, Research, Citations, Industry Income and International Outlook. The area of International Outlook includes three 
criteria namely "Proportion of International Students", "Proportion of International Staff" and "International Collaboration" (THE, 2020). Using the global ranking the top 200 listed Universities' websites were explored in order to retrieve their mission statement. The inclusion criteria utilised statements in English that were distinctly titled "Mission" or "Mission Statement". Universities that had multiple top 200 listings had their mission statement only included once. For the purpose of comparison to the SADC dataset the Top 200 dataset excluded the two African universities (University of the Witwatersrand and University of Cape Town) listed in the top 200. Therefore, the final total of 158 mission statements became the global dataset. Each mission statement was coded according to which continent the University resides. Table 1 displays the distribution of the mission statements according to continent.

Table 2 - Distribution of the mission statements according to continent.

\begin{tabular}{|c|c|}
\hline & Numbers of Mission Statements \\
\hline Europe & 73 \\
\hline North America & 57 \\
\hline Asia & 21 \\
\hline Oceania & 7 \\
\hline
\end{tabular}

\section{Data Analysis}

Text mining utilises language and document processing to extract meaning out of data created by humans (Jung, 2020). In this extraction text mining techniques such as content analysis produce various outputs such as word frequency, word cirrus, keyword network analysis, topic modelling and collocates graphs. In this study content analysis was achieved through a web-based software (Voyant Tools (C). Due to its generalisation of results this approach should be used sparingly (Jung, 2020). However, it has been shown in a study that text mining and qualitative research are epistemologically compatible (Yu, 2020).

Therefore, Voyant Tools (C) allows us to gain insight into the region of SADC and compare it to the global dataset of the Top 200 Universities as ranked by Times Higher Education (THE). Each country's dataset was uploaded separately on Voyant Tools (https://voyant-tools.org/) to gain insight on a country-by-country basis. The entire regions dataset was then uploaded collectively to allow for comparisons to the Top 200 dataset. Before the data analysis dataset was cleaned up utilizing the StopWord function where certain words such as country names can be ignored from the analysis. The software automatically includes conjunctions, prepositions and common words such as "the" and "a" to the system's StopWord list.

\section{IV.RESULTS AND DISCUSSION}

The mission statements' sentences of the SADC corpus are longer than those of the WORLD corpus at an average of 37.2 and 24.4 words respectively. Similar to findings (that had no data from the African continent) by Cortez-Sanchez (2018) that the mission statements from Asia are the lengthiest.

Table 3 - Average words per sentence

\begin{tabular}{|c|c|}
\hline Region/Country & Words Per Sentence \\
\hline SADC & 37.2 \\
\hline WORLD & 37.2 \\
\hline Botswana & 24.4 \\
\hline Eswatini & 25.9 \\
\hline Lesotho & 23.3 \\
\hline Madagascar & 32 \\
\hline Malawi & 36 \\
\hline Mauritius & 22.2 \\
\hline Namibia & 22.8 \\
\hline South Africa & 39.2 \\
\hline Tanzania & 74.9 \\
\hline Zambia & 27.6 \\
\hline Zimbabwe & 43.1 \\
\hline Europe & 21.9 \\
\hline North America & 28.1 \\
\hline Asia & 39.4 \\
\hline Oceania & 26.1 \\
\hline
\end{tabular}

A preliminary search in both corpus (SADC and WORLD) revealed that the word "internationalisation" appears explicitly only once in the SADC corpus by Midlands State University in Zimbabwe which emphasised its commitment to the "internationalisation of higher education". In the WORLD corpus the word is expressed by three European HEIs all located in Germany. The University of Erlangen-Nuremberg states that it is "ready to tackle the challenges of internationalisation" in its mission statement. The University of Hamburg goes as far as stating that it has a dedicated team tackling the goal of internationalisation. Ulm University states that they see "internationalization as an integral part and critical success factor for our overall orientation, development planning and future viability". Digital learning and international mobility are their stated approach to achieve this.

The absence of quantitative objectives in both datasets is akin to findings of other studies (Efe and Ozer, 2015). Supported by findings of Cortés-Sánchez (2018), mission statements are influenced by history, culture and economics of their respective countries. In the SADC corpus this is evident especially regarding HEIs' goal to contribute to economic development.

The Top 25 words cirrus depicts the words with greatest frequency (according to the size of the word) in figure 1. Both corpuses frequent use of the word 'university' is supported by previous studies where HEIs' self-awareness was evident through the expression of their identity (Efe and Ozer, 2015). This self-awareness is one of the components of a mission 
statement outlined as "who are we?" by Arias-Coello et al. (2018) and outlined as "identification of the company selfconcept" by Pearce and David (1987). Adhering to such global tenets of the components of mission statements supports previous studies observation of mission statement sameness (Kosmützky \& Krücken, 2014). The word cirrus further shows that SADC HEIs' mission statements emphasize their provision of high-quality education in order to carry out the role in community and society's development. These findings are similar to Vasudeva (2020) and Guimares (2019) where HEIs in Africa and Brazil were analysed respectively.

Figure 1 - Top 25 Words Cirrus

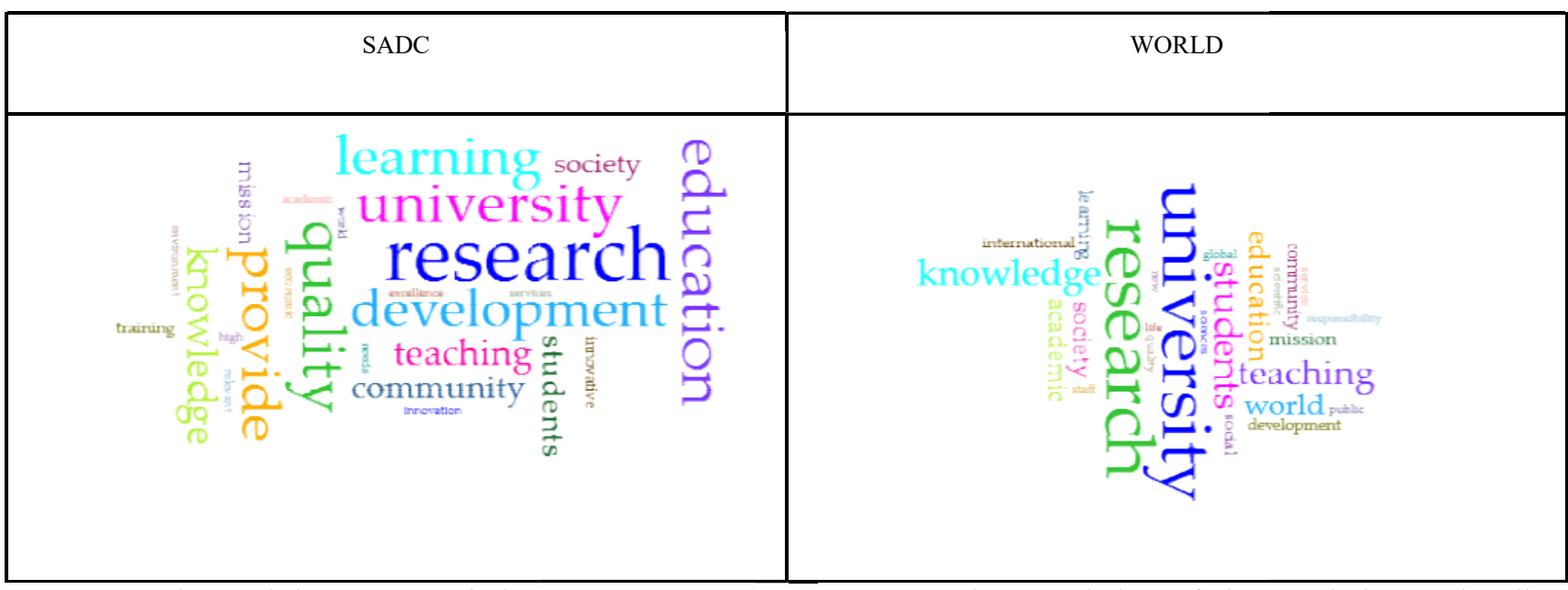

The top 5 words used in SADC mission statements are 'research', 'quality', 'university', 'education' and 'learning'. The emphasis of provision of education in SADC mission statements is akin to findings by Hladchenko's 2016 study of HEIs in Ukraine. For the WORLD corpus the top 5 words utilised are 'university', 'research', 'students', 'teaching' and 'knowledge'.
To gauge the association of the word 'internationalisation' and its related terms 'international', 'internationally', 'internationalists', 'internationalise' were utilized to generate a collate graph of each corpus in figure 3 . International* refers to all the related terms including the word 'internationalisation'. Namibia, Botswana and Zimbabwe had the top three relative use of the terms. While in the WORLD the Oceania continent had the highest relative frequency.

Figure 2 - Relative Frequency of International*

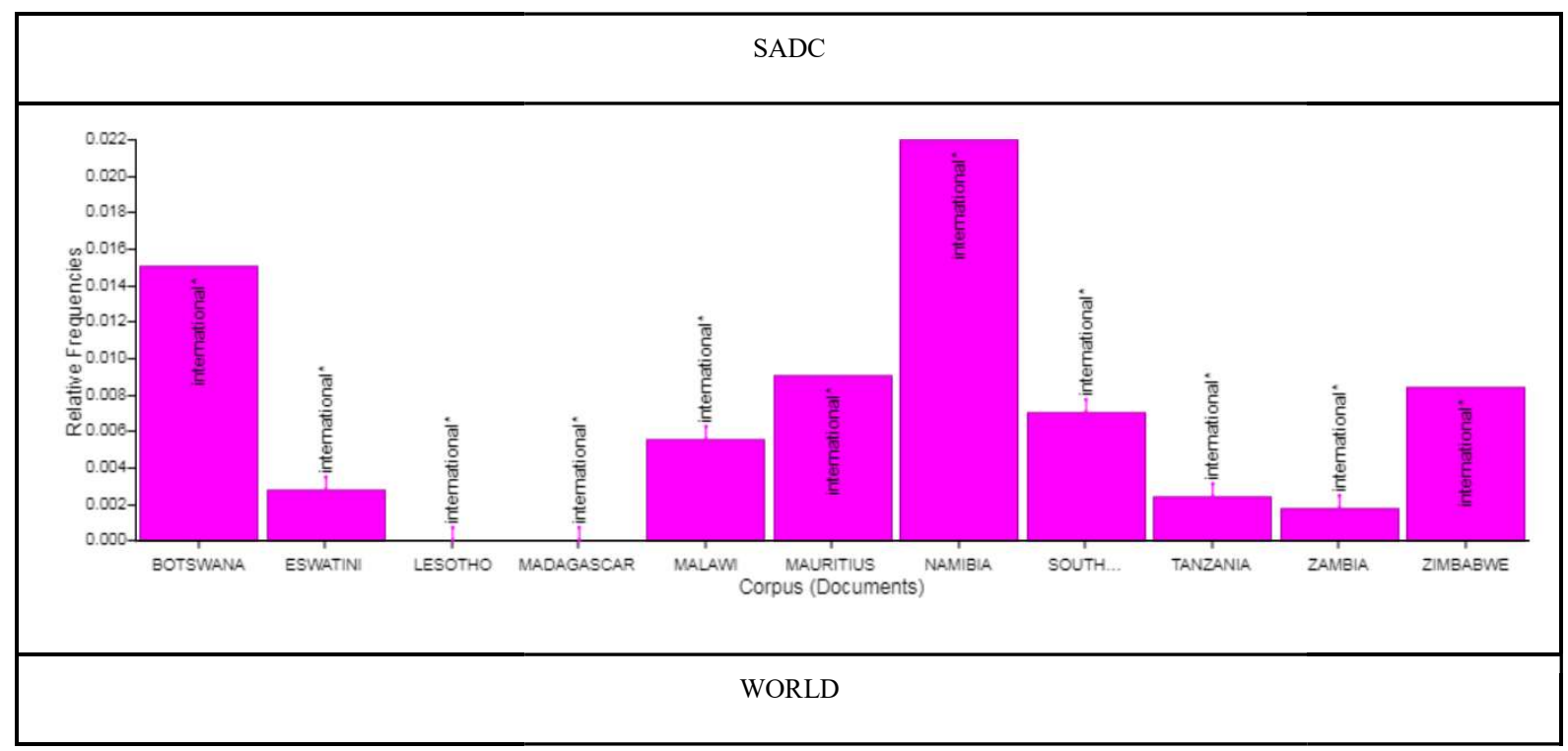




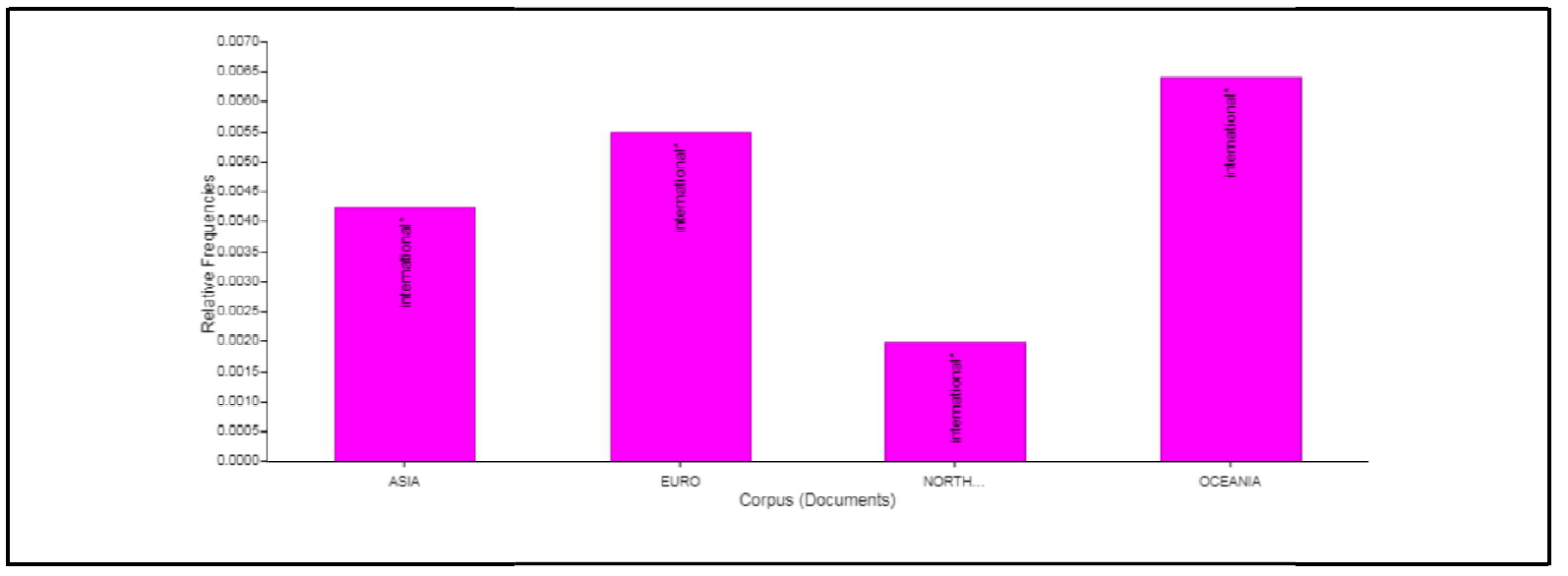

Figure 3 - Collocate Graph

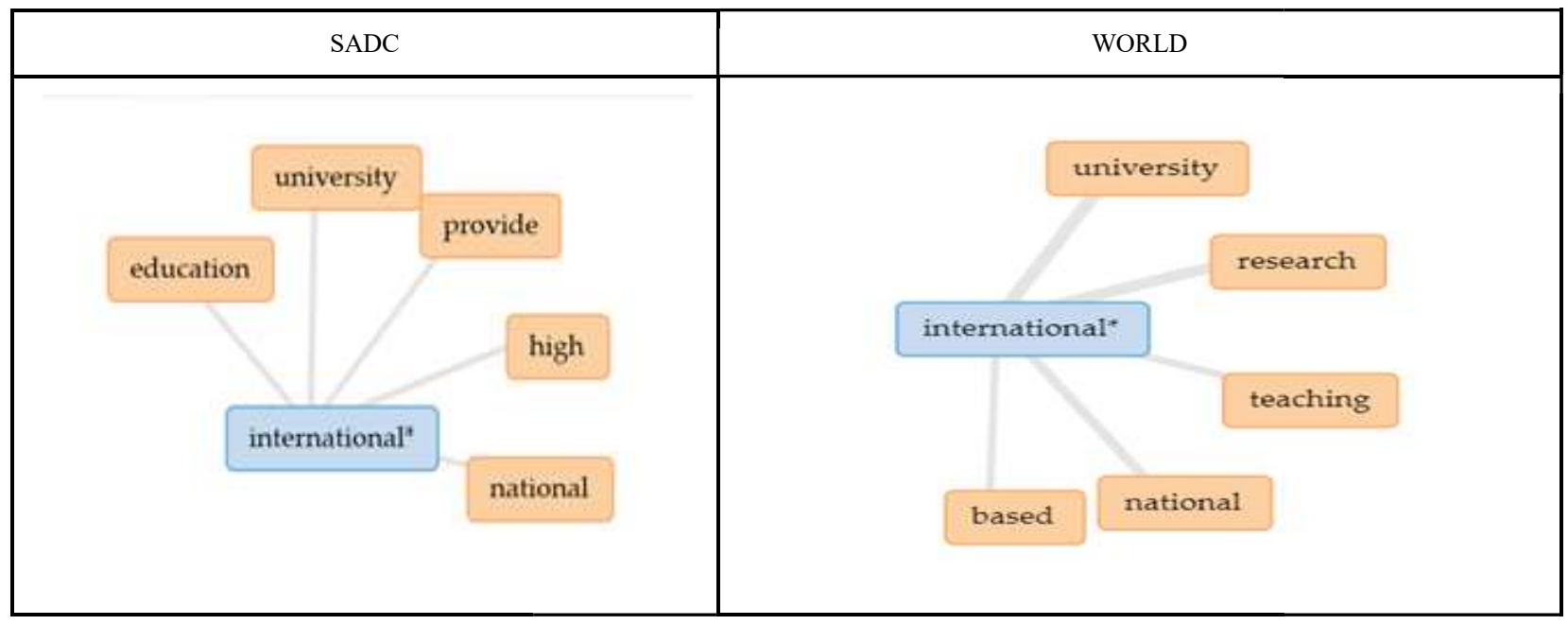

The SADC corpus depicted a collocate graph showing that the terms (International*) are associated with HEI's provision of high standards of education. Further insight on the terms utilising the contexts tool in Voyant (C) which shows the keywords (represented by international*) and its surrounding texts to show the context in which it is utilized. The context tool output in figure 3 showed SADC mission statements to the internationally accredited provision of education. Reference to a regional (SADC) outlook was expressed by a HEI in Botswana stating that its mission is 'advancing itself as a distinctively African university with a regional and international outlook'. The WORLD mission statements associated the terms (International*) with research and teaching. Further insight utilising the context feature shows the terms' association with international exchanges of students and international collaborative research.

Table 4 - Context of International*

\begin{tabular}{|c|c|c|}
\hline \multicolumn{3}{|c|}{ SADC } \\
\hline Left & Term & Right \\
\hline intensive education of an & International* & $\begin{array}{c}\text { Standard. Promote } \\
\text { community, national, } \\
\text { regional }\end{array}$ \\
\hline
\end{tabular}

\begin{tabular}{|c|c|c|}
\hline university with a regional and & International* & Outlook. \\
\hline $\begin{array}{l}\text { of accredited qualifications with } \\
\text { an }\end{array}$ & International* & $\begin{array}{c}\text { standard curriculum } \\
\text { supplemented }\end{array}$ \\
\hline $\begin{array}{c}\text { provide high quality education } \\
\text { of }\end{array}$ & International* & $\begin{array}{l}\text { standards contributing } \\
\text { to the advancement }\end{array}$ \\
\hline and cognisant of continental and & International* & imperatives. \\
\hline \multicolumn{3}{|c|}{ WORLD } \\
\hline Left & Term & Right \\
\hline research on both national and & International* & Topics. \\
\hline translational innovation and & International* & exchange \\
\hline various study abroad programs, & International* & $\begin{array}{l}\text { student and faculty } \\
\text { services }\end{array}$ \\
\hline with local, regional, national and & International* & partners. \\
\hline a first-class university an & International* & exchange in research \\
\hline
\end{tabular}

\section{CONCLUSION}

This exploratory study using a quantitative content analysis approach to analyse and compare mission statements from SADC and the top 200 in the world outlined the international intention of the two datasets. The general consensus from the content analysis agrees with studies that there is 'sameness' in mission statements clusters. This sameness shows a similar 
theme in SADC mission statements in accordance to regional collaborative policies such as the UNESCO report on 'The African University: Into the New Millennium'. However, there are notable continental differences. While this study is expansive in its dataset further probing is needed to delve into countries' legislation regarding internationalisation and its influence on HEIs' mission statements. While both corpuses displayed their international intention with varying approaches the implementation of these intentions is a gap for future studies. In conclusion, this study takes stock of the mission statements in the SADC region and provides an openaccess dataset for future studies and contributes to the few transnational and continental studies especially utilizing global south countries. It is recommended that policy makers (institution, sector and national levels) take stock of their respective HEIs international outlook in the wake of the new normal.

\section{REFERENCES}

[1] Alegre, I., Berbegal-Mirabent, J., Guerrero, A., \& Mas-Machuca, M. (2018). The real mission of the mission statement: A systematic review of the literature. Journal of Management \& Organization, 24(4), 456-473.

[2] Alemu, S. K. (2014). An appraisal of the internationalisation of higher education in sub-Saharan Africa. CEPS Journal, 4(2), 7190.

[3] Altbach, P. G., \& Knight, J. (2007). The internationalization of higher education: Motivations and realities. Journal of Studies in International Education, 11(3-4), 290-305.

[4] Cortés Sánchez, J. D. (2018). Mission statements of universities worldwide: Text mining and visualization. Intangible Capital, 14(4), 584.

[5] Drucker, P. F. (1974). Management: Tasks, responsibilities, practices. Heinemann.

[6] Dumanig, F. P., \& Symaco, L. P. (2020). Internationalisation of higher education in Malaysia and the Philippines: A comparative analysis of mission and vision statements of selected universities. Journal of Multilingual and Multicultural Development, 1-13.

[7] Efe, I., \& Ozer, O. (2015). A corpus-based discourse analysis of the vision and mission statements of universities in turkey. Higher Education Research and Development, 34(6), 1110-1122.

[8] Farrant, J., \& Fielden, J. (1996). Strategic planning in African universities. New Papers on Higher Education, 2

[9] Ganu, J. (2013). Institutional mission statements and attitudinal outcomes of selected faith-based tertiary institutions in Ghana. The Journal of Applied Business and Economics, 14(2), 20.

[10] Gimenez, T. N. (2020). Scholars speak out rethinking the internationalization of higher education in the global south in the wake of a pandemic. Journal of Language and Literacy Education.

[11] Guimarães, F. F., Finardi, K. R., El Kadri, M. S., \& Taquini, R. (2020). The mission statements of the federal universities and the projection of internationalization in brazil. System (Linköping), 94, 102331.

[12] Gyamera, G. O. (2019). The internationalisation agenda: A critical look at the conceptualisation and rationalisation of internationalisation in public universities in Ghana. Compare, 49(6), 924-942.

[13] Hladchenko, M. (2016). The organizational identity of Ukrainian universities as claimed through their mission statements. Tertiary Education and Management, 22(4), 376-389.

[14] Jung, H., \& Lee, B. G. (2020). Research trends in text mining: Semantic network and main path analysis of selected journals. Expert Systems with Applications, 162, 113851.

[15] Kehm, B. M., \& Teichler, U. (2007). Research on internationalisation in higher education. Journal of Studies in International Education, 11(3-4), 260-273.
[16] Ketterer, M. (2015). Analysis of university mission statements and the missions and strategic plans of athletic departments

[17] Knight, J. (2004). Internationalization remodelled: Definition, approaches, and rationales. Journal of Studies in International Education, 8(1), 5-31.

[18] Knight, J. (2013). The changing landscape of higher education internationalisation - for better or worse? Perspectives (Association of University Administrators (U.K.)), 17(3), 84-90.

[19] Kosmützky, A., \& Krücken, G. (2015). Sameness and difference analysing institutional and organizational specificities of universities through mission statements. International Studies of Management \& Organization, 45(2), 137-149.

[20] Majee, U. S. (2020). Beyond the Local-Global binaries of higher education internationalization in post-apartheid South Africa. Journal of Studies in International Education, 24(1), 131-147.

[21] Masaiti, G., \& Mwale, N. (2020). The drive and nature of internationalization of higher education in Zambia. International Journal of African Higher Education, 7(3), 43-51.

[22] Mukwena, M. (2020). Words matter: Content analysis of higher education mission statements in Zambia. International Journal of Research in Education Humanities and Commerce, 1(4)

[23] Oleksiyenko, A., Blanco, G., Hayhoe, R., Jackson, L., Lee, J., Metcalfe, A., Sivasubramaniam, M., \& Zha, Q. (2020). Comparative and international higher education in a new key? thoughts on the post-pandemic prospects of scholarship., 1-17.

[24] Peters, M. A., Rizvi, F., McCulloch, G., Gibbs, P., Gorur, R., Hong, M., Hwang, Y., Zipin, L., Brennan, M., Robertson, S., Quay, J., Malbon, J., Taglietti, D., Barnett, R., Chengbing, W., McLaren, P., Apple, R., Papastephanou, M., Burbules, N., Misiaszek, L. (2020). Reimagining the new pedagogical possibilities for universities post-covid-19: An EPAT collective project. Educational Philosophy and Theory, , 1-44.

[25] Salgado de Oliveira Gomes, Verónica. (2020). The internationalisation of higher education institutions - an analysis of the Portuguese case

[26] Scott, J. C. (2006). The mission of the university: Medieval to postmodern transformations. The Journal of Higher Education: Moving into the Next 75 Years, 77(1), 1-39.

[27] Seeber, M., Barberio, V., Huisman, J., \& Mampaey, J. (2019). Factors affecting the content of universities' mission statements: An analysis of the United Kingdom higher education system. Studies in Higher Education (Dorchester-on-Thames), 44(2), 230244.

[28] Sehoole, C., \& De Wit, H. (2014). The regionalisation, internationalisation, and globalisation of African higher education. International Journal of African Higher Education, 1(1)

[29] Sridhar, S., \& Sequeira, A. H. (2007). Content analysis of mission statements of engineering colleges. Management \& Change, 11(1)

[30] Tamrat, W., \& Teferra, D. (2018). Internationalization of Ethiopian higher education institutions: Manifestations of a nascent system. Journal of Studies in International Education, 22(5), 434-453.

[31] Teichler, U. (2004). The changing debate on internationalisation of higher education. Higher Education, 48(1), 5-26.

[32] Teichler, U. (2017). Internationalisation trends in higher education and the changing role of international student mobility. Journal of International Mobility, (1), 177-216.

[33] Vasudeva, S., \& Mogaji, E. (2020). Paving the way for world domination: Analysis of African universities' mission statement. In Maringe Felix, Hinson Robert Ebo \& Mogaji Emmanuel (Eds.), Understanding the market in higher education in Africa (2020). Abingdon Oxfordshire: Routledge.

[34] Yu, C. H., Jannasch-Pennell, A., \& DiGangi, S. (2011). Compatibility between text mining and qualitative research in the perspectives of grounded theory, content analysis, and reliability. Qualitative Report, 16(3), 730-744. 